Article

\title{
Cytotoxic Xanthones from Hypericum stellatum, an Ethnomedicine in Southwest China
}

\author{
Yuanyuan Ji ${ }^{1,2}$, Ruifei Zhang ${ }^{1,2}{ }^{-1}$, Chen Zhang ${ }^{1}$, Xingyu Li ${ }^{3}$, Adam Negrin ${ }^{4,5}$, Chaonan Yuan ${ }^{1}$, \\ Edward J. Kennelly ${ }^{4,5}$ and Chunlin Long ${ }^{1,2, *}$ \\ 1 College of Life and Environmental Sciences, Minzu University of China, Beijing 100081, China; \\ 18363591863@163.com (Y.J.); ruifeizhang@yeah.net (R.Z.); zcyx3120@163.com (C.Z.); \\ 13161131400@163.com (C.Y.) \\ 2 Key Laboratory of Ethnomedicine, Minzu University of China, Ministry of Education, Beijing 100081, China \\ 3 College of Science, Yunnan Agriculture University, Kunming 650201, China; lixingyu@ynau.edu.cn \\ 4 Department of Biological Sciences, Lehman College, City University of New York, Bronx, NY 10468, USA; \\ adamnegrin@gmail.com (A.N.); edward.kennelly@lehman.cuny.edu (E.J.K.) \\ 5 The Graduate Center, City University of New York, New York, NY 10016, USA \\ * Correspondence: long@mail.kib.ac.cn; Tel.: +86-010-68930381
}

Received: 2 September 2019; Accepted: 27 September 2019; Published: 2 October 2019

check for updates

\begin{abstract}
Hypericum stellatum, a species endemic to China, is used to treat hepatitis by several ethnic groups in Guizhou Province. This research was inspired by the traditional medicinal usage of $H$. stellatum, and aims to explore the phytochemistry and bioactivity of $H$. stellatum to explain why local people in Guizhou widely apply $H$. stellatum for liver protection. In this study, two new prenylated xanthones, hypxanthones A (8) and B (9), together with seven known compounds, were isolated from the aerial parts of the plant. Spectroscopic data as well as experimental and calculated ECD spectra were used to establish the structures of these compounds. Six xanthones isolated in this study, together with four xanthones previously isolated from H. stellatum, were evaluated for their growth-inhibitory activities against five human liver carcinoma cell lines to analyze the bioactivity and structure-activity relationship of xanthones from $H$. stellatum. Isojacareubin (6) showed significant cytotoxicity against five human liver carcinoma cell lines, with an $\mathrm{IC}_{50}$ value ranging from 1.41 to $11.83 \mu \mathrm{M}$, which was stronger than the positive control cisplatin $\left(\mathrm{IC}_{50}=4.47-20.62 \mu \mathrm{M}\right)$. Hypxanthone $\mathrm{B}(9)$ showed moderate cytotoxicity to three of the five cell lines. Finally, structure-activity analysis revealed that the prenyl and pyrano substituent groups of these xanthones contributed to their cytotoxicity.
\end{abstract}

Keywords: Hypericum stellatum; xanthone; liver carcinoma cell lines; cytotoxicity; ethnomedicine

\section{Introduction}

The plants in the genus Hypericum have a long history of use as herbal medicines in China. There are 64 Hypericum species (33 endemic) distributed throughout China [1], and 19 of these species have been used traditionally as medicinal plants with a range of purported benefits, including antidepressant, detoxification, hemostasis, antibacterial, and hepatoprotection activities. Based on ethnobotanical investigations in southeast Guizhou province, eight Hypericum species were found to be used as ethnomedicines by several ethnic groups, including the Shui, Miao, Dong, and She peoples. Previous phytochemical investigations on Hypericum have reported various types of compounds, including naphthodianthrones, flavonoids, prenylated phloroglucinols, and phenols [2-5]. Furthermore, Hypericum extracts have been found to exhibit various pharmacological activities, including antidepressant, antiviral, antibacterial, and anti-HIV activities [6-10].

Hypericum stellatum is an endemic species to China, primarily distributed in Chongqing and surrounding regions. Our ethnobotanical investigations in Majiang, a county of the Qiandongnan Miao 
and Dong Autonomous Prefectures in Guizhou Province, have shown that H. stellatum is used by the local Miao and Buyi people to treat liver diseases such as icterohepatitis. However, no chemical studies had been conducted on this species. In our recent research on H. stellatum, UPLC-Q-TOF-MS was applied to analyze the chemical constituents of the plant. The results showed that $H$. stellatum was rich in flavonoids, phenolic acids, and polycyclic polyprenylated acylphloroglucinols. H. stellatum possesses strong antioxidant activity and a high content of total phenols. Ten compounds, including flavonoids, xanthones, and phenolic acids, were isolated [11]. To further illuminate the plant's pharmacological constituents, we used column chromatography (CC), including silica gel, Sephadex LH-20, and recycling preparative HPLC, which yielded two new xanthones and seven known compounds. Six xanthones (1, 2, and 6-9) obtained in this research, together with four previously isolated xanthones (3-5 and 10), were tested for cytotoxicity against five human liver carcinoma cell lines. Herein, we report the isolation, structure elucidation, and bioactivities of these compounds isolated from H. stellatum.

\section{Results and Discussion}

A $95 \%$ aq. EtOH extract of the aerial part of H. stellatum was suspended in water and extracted successively with petroleum ether, EtOAc, and $n-\mathrm{BuOH}$. The EtOAc extract showed strong antioxidant activity and a high total phenol content. The fraction of EtOAc was repeatedly subjected to silica gel, Sephadex LH-20, and a liquid chromatography loop preparation, yielding two new prenylated xanthones (8 and 9) and seven known compounds. Structures of the new compounds were elucidated using spectroscopic data and calculated via ECD spectra, the spectroscopic data can be seen in Supplementary Materials Figures S1-S16.

Hypxanthone A (8) was obtained as a yellow amorphous powder. Its molecular formula, $\mathrm{C}_{18} \mathrm{H}_{16} \mathrm{O}_{7}$, was established by HR-ESI-MS ( $\mathrm{m} / \mathrm{z} 343.0826[\mathrm{M}-\mathrm{H}]^{-}$, calcd. 343.0823), with 11 degrees of unsaturation. The ${ }^{1} \mathrm{H}-\mathrm{NMR}$ data (Table 1$)$ exhibited signals of one methyl group $\left(\delta_{\mathrm{H}} 1.92(3 \mathrm{H}, \mathrm{s})\right)$, four aromatic protons $\left(\delta_{\mathrm{H}} 5.63(1 \mathrm{H}, \mathrm{t}, J=7.2 \mathrm{~Hz}), 6.22(1 \mathrm{H}, \mathrm{s}), 6.89(1 \mathrm{H}, \mathrm{d}, J=8.4 \mathrm{~Hz}), 7.85(1 \mathrm{H}, \mathrm{d}, J=8.4 \mathrm{~Hz})\right)$, and two methylene groups $\left(\delta_{\mathrm{H}} 3.63(2 \mathrm{H}, \mathrm{d}, J=7.2 \mathrm{~Hz}), 3.91(2 \mathrm{H}, \mathrm{s})\right)$. The ${ }^{13} \mathrm{C}-\mathrm{NMR}$ data of compound 8 revealed the presence of 18 carbons, including one carbonyl, six oxygenated $\mathrm{sp}^{2}$ tertiary carbons, four $\mathrm{sp}^{2}$ quaternary carbons, four aromatic methines, two methylenes, and one methyl group. These results indicated that 8 has a skeleton of prenylated xanthone. Besides, the presence of a prenyl group in 8 was deduced from signals at $\delta_{\mathrm{H}} 3.63 / \delta_{\mathrm{C}} 22.0\left(\mathrm{C}-1^{\prime}\right), \delta_{\mathrm{H}} 5.63 / \delta_{\mathrm{C}} 125.0\left(\mathrm{C}-2^{\prime}\right), \delta_{\mathrm{H}} 3.91 / \delta_{\mathrm{C}} 69.1\left(\mathrm{C}-4^{\prime}\right)$, and $\delta_{\mathrm{H}} 1.92 / \delta_{\mathrm{C}} 14.0\left(\mathrm{C}-5^{\prime}\right)$. The prenyl group was assigned to locate at $\mathrm{C}-4$ based on the HMBC correlations of $\mathrm{H}-1^{\prime} / \mathrm{C}-3, \mathrm{H}-1^{\prime} / \mathrm{C}-4, \mathrm{H}-1^{\prime} / \mathrm{C}-10 \mathrm{a}, \mathrm{H}-1^{\prime} / \mathrm{C}-3^{\prime}, \mathrm{H}_{3}-5^{\prime} / \mathrm{C}-2^{\prime}$, and $\mathrm{H}_{3}-5^{\prime} / \mathrm{C}-4^{\prime}$, as shown in Figure 1 . The ROESY correlation of $\mathrm{H}-2^{\prime} / \mathrm{H}-4^{\prime}$ suggested that the $\Delta^{2^{\prime}\left(3^{\prime}\right)}$ double bond was $E$ configured, thus defining the structure (Figure 1), and this was named hypxanthone A.

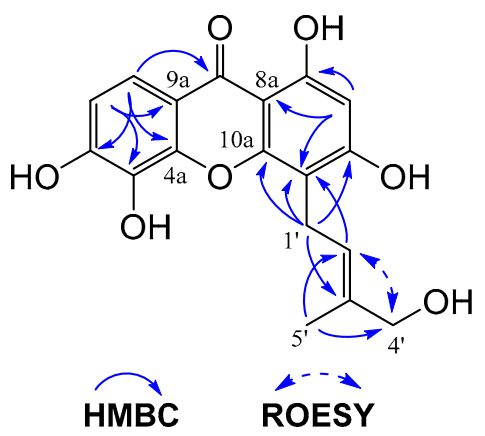

Figure 1. Key HMBC and ROESY correlations of hypxanthone A. 
Table 1. ${ }^{13} \mathrm{C}$ - and ${ }^{1} \mathrm{H}-\mathrm{NMR}$ spectroscopic data $(151 / 600 \mathrm{MHz})$ for hypxanthone A and hypxanthone $\mathrm{B}$ in methanol- $d_{4}(\delta$ in ppm, $J$ in $\mathrm{Hz}$ ).

\begin{tabular}{ccccc}
\hline \multirow{2}{*}{ Position } & \multicolumn{2}{c}{ Hypxanthone A } & \multicolumn{2}{c}{ Hypxanthone B } \\
\cline { 2 - 5 } & $\delta_{\mathbf{C}}$ & $\delta_{\mathbf{H}}$ & $\delta_{\mathbf{C}}$ & $\delta_{\mathbf{H}}$ \\
\hline 1 & 162.6 & & 161.9 & \\
2 & 98.3 & $6.22, \mathrm{~s}$ & 99.2 & $6.14, \mathrm{~s}$ \\
3 & 164.4 & & 162.8 & \\
4 & 107.7 & & 102.6 & \\
5 & 133.4 & & 133.9 & \\
6 & 148.4 & & 148.0 & \\
7 & 113.4 & $6.89, \mathrm{~d}, 8.4$ & 113.8 & $6.90, \mathrm{~d}, 8.4$ \\
8 & 117.5 & $7.85, \mathrm{~d}, 8.4$ & 117.7 & $7.60, \mathrm{~d}, 8.4$ \\
9 & 182.4 & & 182.1 & \\
$4 \mathrm{a}$ & 153.2 & & 153.5 & \\
$8 \mathrm{a}$ & 103.2 & & 103.8 & \\
$9 \mathrm{a}$ & 114.8 & & 115.0 & \\
$10 \mathrm{a}$ & 156.3 & & 156.0 & \\
$1^{\prime}$ & 22.0 & $3.63, \mathrm{~s}$ & 25.4 & $2.90, \mathrm{dd}(11.4,16.2)$ \\
$2^{\prime}$ & 125.0 & $5.63, \mathrm{t}, 6.0$ & 45.7 & $2.50, \mathrm{~m}$ \\
$3^{\prime}$ & 135.9 & & 77.3 & $4.80, \mathrm{t}, 9.0$ \\
$4^{\prime}$ & 69.1 & $3.91, \mathrm{~s}$ & 124.2 & $5.27, \mathrm{~d}, 9.0$ \\
$5^{\prime}$ & 14.0 & $1.92, \mathrm{~s}$ & 140.2 & \\
$6^{\prime}$ & & & 25.9 & $1.80, \mathrm{~s}$ \\
$7^{\prime}$ & & & 18.6 & $1.80, \mathrm{~s}$ \\
$8^{\prime}$ & & & 146.4 & \\
$9^{\prime}$ & & & 113.7 & $4.92, \mathrm{~s}$ \\
$10^{\prime}$ & & & 20.6 & $1.80, \mathrm{~s}$ \\
\hline
\end{tabular}

Hypxanthone $B(9)$ was obtained as yellow amorphous powder. Its molecular formula, $\mathrm{C}_{23} \mathrm{H}_{22} \mathrm{O}_{6}$, was established by HR-ESI-MS $\left(\mathrm{m} / \mathrm{z} 393.1341[\mathrm{M}-\mathrm{H}]^{-}\right.$, calcd. 393.1344), with 13 degrees of unsaturation. The ${ }^{1} \mathrm{H}-\mathrm{NMR}$ data (Table 1$)$ showed resonances characteristic for three methyl groups $\left(\delta_{\mathrm{H}} 1.79(3 \mathrm{H}\right.$, s), $1.80(3 \mathrm{H}, \mathrm{s}), 1.80(3 \mathrm{H}, \mathrm{s}))$ and five aromatic protons $\left(\delta_{\mathrm{H}} 4.92(2 \mathrm{H}, \mathrm{s}), 5.28(1 \mathrm{H}, \mathrm{d}, J=9.0 \mathrm{~Hz}), 6.14\right.$ $(1 \mathrm{H}, \mathrm{s}), 6.90(1 \mathrm{H}, \mathrm{d}, J=8.4 \mathrm{~Hz}), 7.60(1 \mathrm{H}, \mathrm{d}, J=8.4 \mathrm{~Hz}))$. The ${ }^{13} \mathrm{C}-\mathrm{NMR}$ data were similar to those of 8 , except for the additional signals of two methyls, two aromatic carbons, and one methine carbon. The 1D-NMR data indicated that 9 also possesses a prenylated xanthone skeleton. The HSQC and DEPT spectra suggested that there were two double bonds (one terminal double bond), three methyl groups, one methylene, and two methines (one oxygenated carbon). Considering the molecular formula unsaturation, there should be another ring in 9. The ${ }^{1} \mathrm{H}-{ }^{1} \mathrm{H}$ COSY spectrum displayed the correlations of $\mathrm{H}-1^{\prime} / \mathrm{H}-2^{\prime} / \mathrm{H}-3^{\prime} / \mathrm{H}-4^{\prime}$. The HMBC spectrum showed cross peaks from $\mathrm{H}-1^{\prime}$ to $\mathrm{C}-5 / \mathrm{C}-6 / \mathrm{C}-10 \mathrm{a}, \mathrm{H}-3^{\prime}$ to $\mathrm{C}-5^{\prime} / \mathrm{C}-8^{\prime}, \mathrm{H}-7^{\prime}$ to $\mathrm{C}-4^{\prime} / \mathrm{C}-5^{\prime}$, and $\mathrm{H}-9^{\prime}$ to $\mathrm{C}-2^{\prime} / \mathrm{C}-10^{\prime}$, as shown in Figure 2 , thus assigning the planar structure. The $\left(2^{\prime} \beta, 3^{\prime} \alpha\right)$ orientations of substituents in 9 were deduced from the ROESY correlations between $\mathrm{H}-1^{\prime} \mathrm{a}$ and $\mathrm{H}-2^{\prime}, \mathrm{H}-1^{\prime} \mathrm{b}$, and $\mathrm{H}-3^{\prime}$, as shown in Figure 2. The $\left(2^{\prime} S, 3^{\prime} S\right)$ absolute configuration was established via comparison of the experimental and calculated ECD spectra, which displayed cotton effects at 219, 249, and $310 \mathrm{~nm}$ (Figure 3). Thus, the structure of hypxanthone B was elucidated as depicted below.

In addition to hypxanthones A (8) and B (9), seven known compounds were isolated and identified by comparison with their spectroscopic data in the literatures and standard compounds. These known compounds were the following: 2-hydroxy-3-methoxyxanthone (1) [12], 1,3,8-trihydroxyxanthone (2) [13], isojacareubin (6) [14], 1,3,7-trihydroxy-6-methoxyxanthone (7) [15], ethyl 2-[(3,4-dihydroxybenzoyloxy)-4,6-dihydroxyphenyl] acetate [16], $\beta$-sitosterol, and daucosterol. 


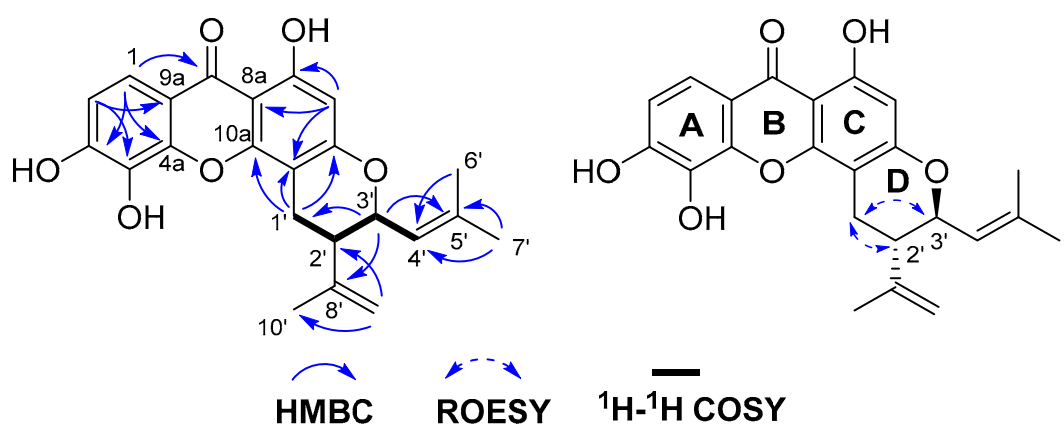

Figure 2. Key ${ }^{1} \mathrm{H}-{ }^{1} \mathrm{H}$ COSY, HMBC and ROESY correlations of hypxanthone B.

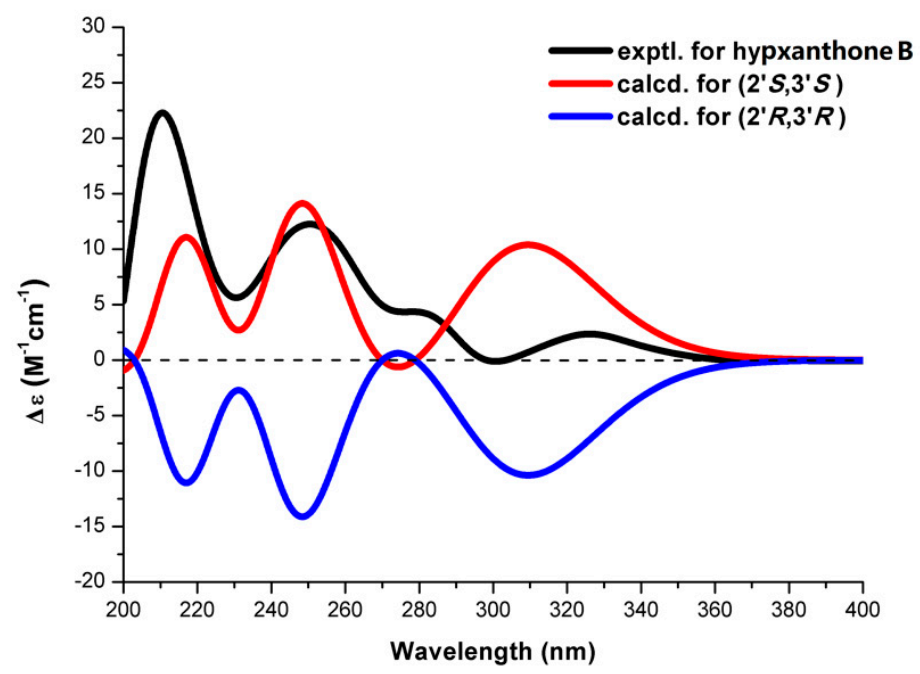

Figure 3. Comparison of experimental (black line) and calculated (red and blue lines) ECD spectra of hypxanthone $\mathrm{B}$.

To evaluate the bioactivity and structure-activity relationship of xanthones from H. stellatum, the xanthones isolated in this research, together with five previously isolated xanthones, 1,3,6,7-tetrahydroxylxanthone (3), 1,3,7-trihydroxyxanthone (4), 3,6,7-trihydroxy-1-methoxyxanthone (5) and calycinoxanthon D (10), were tested for their growth-inhibitory activities against five human liver carcinoma cell lines (SMMC-7721, Huh-7, HepG2, SK-HEP-1, PLC/PRF/5) and against the human normal liver cell line LO2. The structures of the xanthones are shown in Figure 4.

Cytotoxic activity tests (Table 2) showed that simply oxygenated xanthone compounds $\mathbf{3}$ and $\mathbf{5}$ showed weak cytotoxicity against all five cell lines with $\mathrm{IC}_{50}$ values $>40 \mu \mathrm{M}$. This is probably due to the absence of the groups which are crucial to locking the compound into the domain in the target binding site. Compounds 6, 9 (hypxanthone B), and 10 showed strong cytotoxic activity towards SMMC-7721 cells, with $\mathrm{IC}_{50}$ values ranging from 1.41 to $8.26 \mu \mathrm{M}$, while 2, 7, and 8 (hypxanthone A) showed moderate cytotoxic activity against the same cell line. Compound $6\left(\mathrm{IC}_{50}=9.09 \mu \mathrm{M}\right)$ showed strong cytotoxic activity towards Huh-7 cells, and compounds $\mathbf{9}$ and $\mathbf{1 0}$ showed moderate cytotoxic activity towards Huh-7 cells. Compounds 1, 4, 9, and 10 showed moderate cytotoxic activity towards HepG2 cells, and 6 showed strong cytotoxic activity with an $\mathrm{IC}_{50}$ value of $2.40 \mu \mathrm{M}$. Tests on SK-HEP-1 cells showed that compounds 7 and $\mathbf{1 0}$ showed moderate cytotoxic activity, and $\mathbf{6}$ showed strong cytotoxic activity $\left(\mathrm{IC}_{50}=9.20 \mu \mathrm{M}\right)$. Compounds 6, 9, and 10 showed moderate cytotoxic activity towards PLC/PRF/5 cells. 


\begin{tabular}{|c|c|c|c|c|c|c|c|c|}
\hline NO & $\mathrm{R}_{1}$ & $\mathrm{R}_{2}$ & $\mathrm{R}_{3}$ & $\mathrm{R}_{4}$ & $\mathrm{R}_{5}$ & $\mathrm{R}_{6}$ & $\mathrm{R}_{7}$ & $\mathrm{R}_{8}$ \\
\hline 1 & $\mathrm{H}$ & $\mathrm{H}$ & $\mathrm{H}$ & $\mathrm{H}$ & $\mathrm{H}$ & $\mathrm{OMe}$ & $\mathrm{OH}$ & $\mathrm{H}$ \\
\hline 2 & $\mathrm{OH}$ & $\mathrm{H}$ & $\mathrm{OH}$ & $\mathrm{H}$ & $\mathrm{H}$ & $\mathrm{H}$ & $\mathrm{H}$ & $\mathrm{OH}$ \\
\hline 3 & $\mathrm{OH}$ & $\mathrm{H}$ & $\mathrm{OH}$ & $\mathrm{H}$ & $\mathrm{H}$ & $\mathrm{OH}$ & $\mathrm{OH}$ & $\mathrm{H}$ \\
\hline 4 & $\mathrm{OH}$ & $\mathrm{H}$ & $\mathrm{OH}$ & $\mathrm{H}$ & $\mathrm{H}$ & $\mathrm{H}$ & $\mathrm{OH}$ & $\mathrm{H}$ \\
\hline 5 & $\mathrm{OMe}$ & $\mathrm{H}$ & $\mathrm{OH}$ & $\mathrm{H}$ & $\mathrm{H}$ & $\mathrm{OH}$ & $\mathrm{OH}$ & $\mathrm{H}$ \\
\hline 6 & $\mathrm{H}$ & $\mathrm{H}$ & $\mathrm{OH}$ & $\mathrm{OH}$ & \multicolumn{2}{|c|}{-A- } & $\mathrm{H}$ & $\mathrm{OH}$ \\
\hline 7 & $\mathrm{OH}$ & $\mathrm{H}$ & $\mathrm{OH}$ & $\mathrm{H}$ & $\mathrm{H}$ & $\mathrm{OMe}$ & $\mathrm{OH}$ & $\mathrm{H}$ \\
\hline 8 & $\mathrm{OH}$ & $\mathrm{H}$ & $\mathrm{OH}$ & B & $\mathrm{OH}$ & $\mathrm{OH}$ & $\mathrm{H}$ & $\mathrm{H}$ \\
\hline 9 & $\mathrm{OH}$ & $\mathrm{H}$ & \multicolumn{2}{|c|}{$-\mathrm{C}-$} & $\mathrm{OH}$ & $\mathrm{OH}$ & $\mathrm{H}$ & $\mathrm{H}$ \\
\hline 10 & $\mathrm{OH}$ & $\mathrm{H}$ & $\mathrm{OH}$ & D & $\mathrm{OH}$ & $\mathrm{OH}$ & $\mathrm{H}$ & $\mathrm{H}$ \\
\hline
\end{tabular}

Figure 4. Structures of xanthone derivatives from H. stellatum.

Table 2. $\mathrm{IC}_{50}$ values of xanthones from $H$. stellatum.

\begin{tabular}{ccccccc}
\hline \multirow{2}{*}{ Compds } & \multicolumn{7}{c}{ IC $_{\mathbf{5 0}} \pm$ SD $(\boldsymbol{\mu M})$} \\
\cline { 2 - 7 } & SMMC-7721 & Huh-7 & HepG2 & SK-HEP-1 & PLC/PRF/5 & LO2 \\
\hline $\mathbf{1}$ & $>40$ & $>40$ & $10.19 \pm 0.12$ & $>40$ & $>40$ & $14.47 \pm 0.95$ \\
$\mathbf{2}$ & $15.20 \pm 0.27$ & $>40$ & $>40$ & $>40$ & $>40$ & $>40$ \\
$\mathbf{4}$ & $>40$ & $>40$ & $22.60 \pm 1.43$ & $>40$ & $>40$ & $>40$ \\
$\mathbf{6}$ & $1.41 \pm 0.03$ & $9.09 \pm 0.38$ & $2.40 \pm 0.02$ & $9.20 \pm 0.21$ & $11.83 \pm 0.56$ & $2.03 \pm 0.04$ \\
$\mathbf{7}$ & $28.18 \pm 0.89$ & $>40$ & $>40$ & $37.09 \pm 0.97$ & $>40$ & $12.09 \pm 0.14$ \\
$\mathbf{8}$ & $27.56 \pm 0.68$ & $>40$ & $>40$ & $>40$ & $>40$ & $>40$ \\
$\mathbf{9}$ & $8.26 \pm 0.57$ & $25.77 \pm 2.04$ & $11.93 \pm 0.10$ & $>40$ & $30.76 \pm 0.38$ & $>40$ \\
$\mathbf{1 0}$ & $6.27 \pm 0.16$ & $16.65 \pm 0.24$ & $21.33 \pm 0.16$ & $31.11 \pm 2.67$ & $24.89 \pm 0.46$ & $12.21 \pm 0.25$ \\
Cisplatin $^{a}$ & $4.47 \pm 0.27$ & $16.00 \pm 0.95$ & $10.29 \pm 0.50$ & $20.62 \pm 1.03$ & $10.66 \pm 0.80$ & $13.93 \pm 0.87$ \\
Taxol $^{a}$ & $0.18 \pm 0.03$ & $0.11 \pm 0.011$ & $<0.01$ & $<0.01$ & $<0.01$ & $<0.01$ \\
\hline
\end{tabular}

$\mathrm{IC}_{50} \leq 10=$ strong activity, $10<\mathrm{IC}_{50} \leq 40=$ moderate activity, $\mathrm{IC}_{50}>40=$ weak activity. Each date represents the mean of three independent experiments. ${ }^{\text {a }}$ Positive control.

Compounds which showed strong cytotoxic activity were shown to have prenyl groups, including compounds 9 and 10. Isojacareubin (6), with its pyrano substituent group, showed strong cytotoxic activity to four human liver carcinoma cell lines (SMMC-7721, Huh-7, HepG 2, SK-HEP-1), and its cytotoxic activity was greater than that of the positive control cisplatin (Meilunbio, CAS No. 15663-27-1). However, it also exhibited strong cytotoxic activity to human normal liver cell line LO2. Isojacareubin has been isolated from many Hypericum species, including Hypericum sarothranol [17], Hypericum roeperanum [18], Hypericum japonicum [19] and Hypericum henryi [20], and it has been found to be the most potent cytotoxic compound against various cancer cells including HeLa, A549, PANC-1, HL-7702 [21], AGs, MCF7, MDAMB-231, and U87 [22]. Considering their chemical structure-activity relationships, the prenyl and pyrano substituent groups of the xanthone derivatives likely contributed 
to the cytotoxicity of these compounds against human liver carcinoma cell lines (SMMC-7721, Huh-7, HepG2, SK-HEP-1, PLC/PRF/5).

As active secondary metabolites, xanthones commonly occur in various herbal medicines; a total of 168 species of herbal plants belonging to 58 genera and 24 families have been found to contain xanthones. Calophyllaceae, Gentianaceae and Clusiaceae (Guttiferae) are the most widely distributed families containing xanthones [23]. In Clusiaceae sensu lato, two genera (Hypericum and Garcinia) are rich in variously oxidized and prenylated xanthones, such as Hypericum uralum [24], Hypericum monogynum [25], Hypericum riparium [26], Garcinia nujiangensis [22], Garcinia cowa [21], and Garcinia mangostana [27]. Many of the compounds isolated from these plants could have remarkable medicinal potential, such as the prenylated xanthone gambogic acid isolated from Garcinia hanburyi. The resin of G. hanburyi, called gamboge in traditional Chinese medicine and ethnomedicine in Asian countries, possesses broad-spectrum anticancer activity and showed safety in Chinese phase II clinical trials carried out in 2009 [28]. Furthermore, our own research, as well as previous studies, has revealed that isojacareubin possesses potential medicinal value. Isojacareubin has been synthesized, and was found to be a potent inhibitor of PKC; these findings identify isojacareubin as a promising lead compound for the development of new antihepatoma agents [29].

Our previous study revealed that the antioxidant ability and total phenol content of EtOAc and $n$-BuOH extract showed little differences. However, the metabolite profiles of two extractions metabolic profile showed obvious differences. As a result, the $n-\mathrm{BuOH}$ extract should likely contain different biomarkers [11]. Further phytochemical research on the $n$-BuOH extraction will be carried out to search for candidates lead compounds.

\section{Materials and Methods}

\subsection{General Experimental Procedures}

One-dimensional (1D) and two-dimensional (2D) nuclear magnetic resonance (NMR) spectra were recorded on Bruker DRX-600 NMR spectrometers (Bruker, Bremerhaven, Germany), with tetramethylsilane (TMS) as an internal standard. Mass spectrometry (MS) data were collected using Shimadzu liquid chromatography-mass spectrometry-ion-trap-time of flight (LCMS-IT-TOF) (Shimadzu, Kyoto, Japan). Column chromatography was performed using silica gel (100-200 mesh and 200-300 mesh, Qingdao Haiyang Chemical, Inc. Qingdao, China), Sephadex LH-20 (GE Healthcare Bio-Sciences AB, Uppsala, Sweden; $2.5 \mathrm{~cm} \times 150 \mathrm{~cm}$, amount of resin $160 \mathrm{~g}$, at a flow rate of $1 \mathrm{~mL} / \mathrm{min}$ ), and precoated TLC with silica gel 60 GF254 (Qingdao Haiyang Chemical, Inc.). The recycling preparative HPLC system LC-908-G30 (JAI, Japan Analytical Industry Co., Ltd., Tokyo, Japan), equipped with a JAIGEL-ODS-AP-L, SP-120-15 column (Serial No. 051,205,128 Japan Analytical Industry Co., Ltd., Tokyo, Japan) was used in sample purification.

\subsection{Plant Material}

The aerial parts of Hypericum stellatum N. Robson were collected from Majiang County, Qiandongnan Miao and Dong Autonomous Prefectures, Guizhou Province, China, in July 2016. The plant was identified by Jun Yang, a taxonomist at the Kunming Institute of Botany, Chinese Academy of Sciences. A voucher specimen (No. LongCL-060) has been deposited at the Key Laboratory of Economic Plants and Biotechnology, Kunming Institute of Botany.

\subsection{Extraction and Isolation}

The powdered, air-dried aerial parts of $\mathrm{H}$. stellatum $(5 \mathrm{~kg})$ were extracted with $95 \%$ aq. EtOH $(3 \times 16 \mathrm{~L}, 3 \mathrm{~h})$ and subsequently concentrated under vacuum to yield a crude extract $(920.0 \mathrm{~g})$. The crude extract was suspended in $\mathrm{H}_{2} \mathrm{O}(4 \mathrm{~L})$ and successively extracted with petroleum ether $(4.0 \mathrm{~L} \times 3)$, EtOAc $(4.0 \mathrm{~L} \times 3)$ and $n$-BuOH $(4.0 \mathrm{~L} \times 3)$, to obtain the petroleum ether extract $(211.0 \mathrm{~g})$, EtOAc extract $(390.0 \mathrm{~g})$, and $n$ - $\mathrm{BuOH}$ extract $(295.0 \mathrm{~g})$. The EtOAc extract $(390.0 \mathrm{~g})$ was subjected to silica 
gel CC, and eluted with $\mathrm{CH}_{2} \mathrm{Cl}_{2} / \mathrm{CH}_{3} \mathrm{OH}(50: 1$ to $0: 1, v / v)$, yielding 11 fractions (Fr. 1-Fr. 11). Fr. 3 was subjected to silica gel $\mathrm{CC}$ and eluted with $\mathrm{CHCl}_{3} / \mathrm{CH}_{3} \mathrm{OH}(100: 1$ to $1: 1, v / v)$ to afford six fractions (Fr. A1-Fr. A6). Fr. A2 fractionated by Sephadex $\mathrm{LH}-20\left(\mathrm{CHCl}_{3} / \mathrm{CH}_{3} \mathrm{OH} 1: 1, v / v\right)$ into four fractions (Fr. A2a-Fr. A2d). Fr. A2a was submitted to recycling preparative HPLC $\left(\mathrm{CH}_{3} \mathrm{OH}\right)$ to afford 2-hydroxy-3-methoxyxanthone (4.5 mg) and 1,3,8-trihydroxyxanthone (3.9 mg). Fr. 5 was subjected to silica gel CC using (50:1 to $4: 1, v / v)$ to afford 10 fractions (Fr. B1-Fr. B10). Fr. B4 was purified by Sephadex LH-20 $\left(\mathrm{CHCl}_{3} / \mathrm{CH}_{3} \mathrm{OH} 1: 1, v / v\right)$ and submitted to recycling preparative $\mathrm{HPLC}\left(\mathrm{CH}_{3} \mathrm{OH}\right)$ to afford isojacareubin $(1.5 \mathrm{mg})$. Fr. 7 was subjected to silica gel CC using (40:1 to 10:1, v/v) to afford eight fractions (Fr. C1-Fr. C8). Crystallization of Fr. C4 yielded 1,3,7-trihydroxy-6-methoxyxanthone $(1.8 \mathrm{mg})$. Fr. C5 was fractionated by Sephadex $\mathrm{LH}-20\left(\mathrm{CHCl}_{3} / \mathrm{CH}_{3} \mathrm{OH} 1: 1, v / v\right)$ into five fractions (Fr. C5a-Fr. C5e). Fr. C5a was submitted to recycling preparative HPLC $\left(\mathrm{CH}_{3} \mathrm{OH}\right)$ to afford ethyl 2-[(3,4-dihydroxybenzoyloxy)-4,6-dihydroxyphenyl] acetate (1.7 mg) and $\beta$-sitosterol (3.5 mg). Fr. 8 was subjected to silica gel CC using $(50: 1$ to $4: 1, v / v)$ to afford 10 fractions (Fr. D1-Fr. D10). Fr. D7 was fractionated by Sephadex LH-20 $\left(\mathrm{CHCl}_{3} / \mathrm{CH}_{3} \mathrm{OH} 1: 1, v / v\right)$ into three fractions (Fr. D7a-Fr. D7c). Fr. D7b was submitted to recycling preparative $\mathrm{HPLC}\left(\mathrm{CH}_{3} \mathrm{OH}\right)$ to afford hypxanthone A $(1.4 \mathrm{mg})$, hypxanthone B (1.2 mg), and daucosterol (4.5 mg).

\subsection{ECD Calculations}

The method used for ECD calculation has been previously reported [30]. The ROESY spectra were used to initially determine the relative configuration of hypxanthone B, followed by the MMFF94s force field (random conformational analysis). The B3LYP/6-31G(d) level of time-dependent density functional theory (TDDFT) was used to optimize the obtained conformers and was followed by ECD calculations via the TDDFT method (B3LYP/6-31+G(d), CPCM model = MeOH), with SpecDis v1.51 (with a half-bandwidth of $0.3 \mathrm{eV}$ ) to simulate the Boltzmann-weighted ECD spectra. The Gaussian 09 electronic structure package (version 7.0, Gaussian, Inc., Wallingford, CT, USA) was used to perform all of the calculations.

\subsection{Characterization}

Hypxanthone A. Yellow amorphous powder; UV (MeOH) $\lambda \max (\log \varepsilon) 327(4.32) \mathrm{nm} ;{ }^{1} \mathrm{H}-$ and ${ }^{13}$ C-NMR data: see Table 1 ; HRESIMS $m / z 343.0826[\mathrm{M}-\mathrm{H}]^{-}$(calcd. for $\mathrm{C}_{18} \mathrm{H}_{15} \mathrm{O}_{7}, 343.0823$ ).

Hypxanthone B. Yellow amorphous powder; $[\alpha]_{\mathrm{D}}^{25}+75($ c $0.04, \mathrm{MeOH}) ; \mathrm{UV}(\mathrm{MeOH}) \lambda \max (\log \varepsilon)$ 330 (3.44) nm; ECD (c $\left.1.01 \times 10^{-3} \mathrm{M}, \mathrm{MeOH}\right) \lambda \max (\Delta \varepsilon) 210(+33.3), 250(+18.4), 326(+3.5) \mathrm{nm}$; ${ }^{1} \mathrm{H}-$ and ${ }^{13} \mathrm{C}-\mathrm{NMR}$ data: see Table 1 ; HRESIMS m/z $393.1341[\mathrm{M}-\mathrm{H}]^{-}$(calcd. for $\mathrm{C}_{23} \mathrm{H}_{19} \mathrm{O}_{6}$, 393.1344).

\subsection{MTS Assay}

Considering its purported medicinal value for the treatment of liver disease, we tested the cytotoxic activities of ten xanthones isolated from $H$. stellatum against five human liver carcinoma cell lines (SMMC-7721, Huh-7, HepG2, SK-HEP-1, PLC/PRF/5), as well as the immortalized non-cancerous human liver cell (LO2) by the MTS method, in vitro, with cisplatin (CAS No. 15663-27-1, Meilunbio, Dalian, China) and Taxol (CAS No. 33069-62-4, Meilunbio, Dalian, China) as positive controls.

The isolated compounds were tested in vitro for their cytotoxicity to five human liver carcinoma cell lines (SMMC-7721, Huh-7, HepG2, SK-HEP-1, PLC/PRF/5) and the immortalized noncancerous human liver cell (LO2), in a 3-(4,5-dimethylthiazol-2-yl)5(3-carboxymethoxyphenyl)2-(4-sulfopheny)-2H-tetrazolium (MTS; Promega, Beijing, China) assay [31] . In general, cells in the log phase of their cycle were seeded in 96-well plates (4000-5000 cells/well, NEST Biotechnology, Wuxi, China) in a $100-\mu \mathrm{L}$ volume. After $12 \mathrm{~h}$ of incubation at $37^{\circ} \mathrm{C}$, each test compound was added. The cancer cell lines were exposed to the test compounds at five concentrations $(0.064,0.32,1.6,8$, and $40 \mu \mathrm{M})$ in triplicate with cisplatin (Meilunbio, CAS No. 15663-27-1) and Taxol (Meilunbio, CAS No. 33069-62-4) as the positive control. After incubation for $48 \mathrm{~h}$ at $37^{\circ} \mathrm{C}, 20 \mu \mathrm{L}$ of MTS solution and $100 \mu \mathrm{L}$ DMEM were added into the well. The incubation continued for another 
1-4 h. The absorbance was measured at the detection wavelength of $490 \mathrm{~nm}(\mathrm{L1})$ and the reference wavelength of $680 \mathrm{~nm}(L 2)$, and cytotoxicity for each compound was expressed as $\mathrm{IC}_{50}$ values by Reed and Muench's method [32].

\section{Conclusions}

In summary, two new compounds, hypxanthone A (8) and hypxanthone B (9), and seven known compounds (2-hydroxy-3-methoxyxanthone (1), 1,3,8-trihydroxyxanthone, isojacareubin (2), Isojacareubin (6) 1,3,7-trihydroxy-6-methoxyxanthone (7), ethyl 2-[(3,4-dihydroxybenzoyloxy)4,6-dihydroxyphenyl] acetate, $\beta$-sitosterol, and daucosterol) were isolated and identified from $H$. stellatum. Ten xanthones (six xanthones including compounds 1, 2, and 6-9 isolated in this research, along with four xanthones including 3-5 and $\mathbf{1 0}$ isolated previously) isolated from $\mathrm{H}$. stellatum were tested for their cytotoxicity against five human liver carcinoma cell lines. Isojacareubin showed stronger cytotoxic activity than the positive control cisplatin; however, it was weaker than Taxol. Analysis of the structure-activity relationship suggested that xanthone derivatives bearing substituent groups such as prenyl and pyrano groups can improve cytotoxicity towards the tested cancer cell lines. These results indicated that $H$. stellatum is rich in xanthones. The indigenous knowledge leading local people in Guizhou to apply H. stellatum for liver protection and to treat hepatitis needs further research to reveal in order to reveal the mechanisms.

Supplementary Materials: The supplementary materials are available online. ${ }^{1} \mathrm{H}-\mathrm{NMR},{ }^{13} \mathrm{C}-\mathrm{NMR}, \mathrm{HSQC}$, HMBC, ${ }^{1} \mathrm{H}-{ }^{1} \mathrm{H}$ COSY, ROESY, HR-ESI-MS, and UV spectra for hypxanthone A and hypxanthone $\mathrm{B}$ can be seen in Figures S1-S16.

Author Contributions: Y.J. conducted the field investigation, performed experiments, and prepared the draft. R.Z. helped to elucidate structures. C.Z. conducted the ECD calculations. X.L. and C.Y. helped to discuss the SAR. E.J.K. and A.N. edited the English and provided useful comments. C.L. conceived and designed the study, and edited the manuscript.

Funding: This work was supported by the National Natural Science Foundation of China (31870316 \& 31761143001), the Key Laboratory of Ethnomedicine (Minzu University of China) of the Ministry of Education of China (KLEM-ZZ201904, KLEM-ZZ201906), the Jiansheng Fresh Herb Medicine R \& D Foundation (JSYY-20190101-043), the Ministry of Education of China and State Administration of Foreign Experts Affairs of China (B08044), and the Independent Research Project for Doctoral Candidate of Minzu University of China (BBZZKY-2019082), the China Scholarship Council (201906390021).

Acknowledgments: We are grateful to the local people for their assistance in the field investigations and for sharing their valuable knowledge. Thanks are given to J.Y. who identified the voucher specimen. Eric Miller from the University of California at San Francisco provided helpful comments.

Conflicts of Interest: The authors declare no conflict of interest.

\section{References}

1. Li, X.W.; Li, J.; Robson, N.K.B.; Stevens, P.F. Clusiaceae. In Flora of China; Wu, Z.Y., Raven, P., Hong, D.Y., Eds.; Science Press: Beijing, China; Missouri Botanical Garden Press: St. Louis, MO, USA, 2007; Volume 13, pp. 1-34.

2. Barnes, J.; Anderson, L.A.; Phillipson, J.D. St John's wort (Hypericum perforatum L.): A review of its chemistry, pharmacology and clinical properties. J. Pharm. Pharmacol. 2010, 53, 583-600. [CrossRef] [PubMed]

3. Nahrstedt, A.; Butterweck, V. Biologically active and other chemical constituents of the herb of Hypericum perforatum L. Pharmacopsychiatry 1997, 30 (Suppl. 2), 129-134. [CrossRef] [PubMed]

4. Butterweck, V.; Jürgenliemk, G.; Nahrstedt, A.; Winterhoff, H. Flavonoids from Hypericum perforatum show antidepressant activity in the forced swimming test. Planta Med. 2000, 66, 3-6. [CrossRef] [PubMed]

5. Yang, X.W.; Grossman, R.B.; Xu, G. Research progress of polycyclic polyprenylated acylphloroglucinols. Chem. Rev. 2018, 118, 3508-3558. [CrossRef]

6. Bonaterra, G.A.; Schwendler, A.; Huther, J.; Schwarzbach, H.; Schwarz, A.; Kolb, C.; Abdel-Aziz, H.; Kinscherf, R. Neurotrophic, cytoprotective, and anti-inflammatory effects of St. John's wort extract on differentiated mouse hippocampal HT-22 neurons. Front. Pharmacol. 2018, 8, 13. [CrossRef] 
7. Chatterjee, S.S.; Bhattacharya, S.K.; Wonnemann, M.; Singer, A.; Müller, W.E. Hyperforin as a possible antidepressant component of Hypericum extracts. Life Sci. 1997, 63, 499-510. [CrossRef]

8. Wu, R.R.; Le, Z.J.; Wang, Z.Z.; Tian, S.Y.; Xue, Y.B.; Chen, Y.; Hu, L.Z.; Zhang, Y.H. Hyperjaponol H, A new bioactive filicinic acid-based meroterpenoid from Hypericum japonicum Thunb. ex Murray. Molecules 2018, 23, 683. [CrossRef]

9. Zou, Y.; Lu, Y.; Wei, D. Antioxidant activity of a flavonoid-rich extract of Hypericum perforatum L. in vitro. J. Agric. Food Chem. 2004, 52, 5032-5039. [CrossRef]

10. Sanna, C.; Scognamiglio, M.; Fiorentino, A.; Corona, A.; Graziani, V.; Caredda, A.; Cortis, P.; Montisci, M.; Ceresola, E.R.; Canducci, F.; et al. Prenylated phloroglucinols from Hypericum scruglii, an endemic species of Sardinia (Italy), as new dual HIV-1 inhibitors effective on HIV-1 replication. PLoS ONE 2018, 13, e0195168. [CrossRef]

11. Ji, Y.Y.; Engrin, A.; Kennelly, J.E.; Long, C.L. Chemical constituents of Hypericum stellatum and their antioxidant bioactivities. China J. Chin. Mater. Med. 2018, 43, 3701-3707.

12. Gunatilaka, A.L.; De Silva, A.J.; Sotheeswaran, S. Minor xanthones of Hypericum mysorense. Phytochemistry 1982, 21, 1751-1753. [CrossRef]

13. Ungwitayatorn, J.; Pickert, M.; Frahm, A.W. Quantitative structure-activity relationship (QSAR) study of polyhydroxyxanthones. Pharm. Acta. Helv. 1997, 72, 23-29. [CrossRef]

14. Zhou, Z.B.; Zhang, Y.M.; Luo, J.G.; Kong, L.Y. Cytotoxic polycyclic polyprenylated acylphloroglucinol derivatives and xanthones from Hypericum attenuatum. Phytochem. Lett. 2016, 15, 215-219. [CrossRef]

15. Pinheiro, T.R.; Filho, V.C.; Santos, A.R.S.; Calixto, J.B.; Monache, F.D.; Pizzolatti, M.G.; Yunes, R.A. Three xanthones from polygala cyparissias. Phytochemistry 1998, 48, 725-728. [CrossRef]

16. Li, J.; Deng, Y.; Yuan, C.H.; Pan, L.; Chai, H.; Keller, W.J.; Kinghorn, A.D. Antioxidant and quinone reductase-inducing constituents of black chokeberry (Aronia melanocarpa) fruits. J. Agric. Food Chem. 2012, 60, 11551-11559. [CrossRef]

17. Ishiguro, K.; Nagata, S.; Fukumoto, H.; Yamaki, M.; Isoi, K.; Oyama, Y. An isopentenylated flavonol from Hypericum japonicum. Phytochemistry 1993, 32, 1583-1585. [CrossRef]

18. Rath, G.; Potterat, O.; Mavi, S.; Hostettmann, K. Xanthones from Hypericum roeperanum. Phytochemistry 1996, 43, 513-520. [CrossRef]

19. Zhou, G.Y.; An, J.; Han, J.; Zhang, Y.L.; Wang, G.C.; Hao, X.Y.; Bian, Z.Q. Isojacareubin from the Chinese herb Hypericum japonicum: Potent antibacterial and synergistic effects on clinical methicillin-resistant Staphylococcus aureus (MRSA). Int. J. Mol. Sci. 2012, 13, 8210-8218.

20. Wu, Q.L.; Wang, S.P.; Du, L.J.; Yang, J.S.; Xiao, P.G. Xanthones from Hypericum japonicum and H. henryi. Phytochemistry 1998, 49, 1395-1402. [CrossRef]

21. Xia, Z.X.; Zhang, H.; Xu, D.Q.; Lao, Y.Z.; Fu, W.W.; Tan, H.S.; Cao, P.; Yang, L.; Xu, H.X. Xanthones from the leaves of Garcinia cowa induce cell cycle arrest, apoptosis, and autophagy in cancer cells. Molecules 2015, 20, 11387-11399. [CrossRef]

22. Xia, Z.X.; Zhang, D.D.; Liang, S.; Lao, Y.Z.; Zhang, H.; Tan, H.S.; Chen, S.L.; Wang, X.H.; Xu, H.X. Bioassay-guided isolation of prenylated xanthones and polycyclic acylphloroglucinols from the leaves of Garcinia nujiangensis. J. Nat. Prod. 2012, 75, 1459-1464. [CrossRef] [PubMed]

23. Ruan, J.Y.; Zheng, C.; Liu, Y.X.; Qu, L.; Yu, H.Y.; Han, L.F.; Zhang, Y.; Wang, T. Chemical and biological research on herbal medicines rich in xanthones. Molecules 2017, 22, 1698. [CrossRef] [PubMed]

24. Zhang, J.J.; Yang, J.; Liao, Y.; Yang, X.Y.; Ma, J.Z.; Xiao, Q.L.; Yang, L.X.; Xu, G. Hyperuralones A and B, New acylphloroglucinol derivatives with intricately caged cores from Hypericum uralum. Org. Lett. 2014, 16, 4912-4915. [CrossRef]

25. Xu, W.J.; Li, R.J.; Quasie, O.; Yang, M.H.; Kong, L.Y.; Luo, J. Polyprenylated tetraoxygenated xanthones from the roots of Hypericum monogynum and their neuroprotective activities. J. Nat. Prod. 2016, 79, 1971-1981. [CrossRef] [PubMed]

26. Tala, M.F.; Talontsi, F.M.; Zeng, G.Z.; Wabo, H.K.; Tan, N.H.; Spiteller, M.; Tane, P. Antimicrobial and cytotoxic constituents from native Cameroonian medicinal plant Hypericum riparium. Fitoterapia 2015, 102, 149-155. [CrossRef]

27. Ryu, H.W.; Cho, J.K.; Curtislong, M.J.; Yuk, H.J.; Kim, Y.S.; Jung, S.; Kim, Y.S.; Lee, B.W.; Park, K.H. $\alpha$-Glucosidase inhibition and antihyperglycemic activity of prenylated xanthones from Garcinia mangostana. Phytochemistry 2011, 72, 2148-2154. [CrossRef] [PubMed] 
28. Yi, C.; Zhan, X.K.; Yang, L.; Cui, C.X.; Wang, J.W. Phase II a trial to treat advanced malignant tumor using gambogic acid. In Proceedings of the 3rd National Symposium on Medical Oncology, Beijing, China, 23 July 2009.

29. Yuan, X.; Chen, H.; Li, X.; Dai, M.; Zeng, H.W.; Shan, L.; Sun, Q.Y.; Zhang, W.D. Inhibition of protein kinase C by isojacareubin suppresses hepatocellular carcinoma metastasis and induces apoptosis in vitro and in vivo. Sci. Rep. 2015, 5, 12889. [CrossRef]

30. Zhang, R.F.; Feng, X.; Su, G.Z.; Mu, Z.J.; Zhang, H.X.G.; Zhao, Y.N.; Jiao, S.G.; Cao, L.; Chen, S.; Tu, P.F.; et al. Bioactive sesquiterpenoids from the peeled stems of Syringa pinnatifolia. J. Nat. Prod. 2018, 81, 1711-1720. [CrossRef]

31. Zhu, H.C.; Chen, C.M.; Yang, J.; Li, X.N.; Liu, J.J.; Sun, B.; Huang, S.X.; Li, D.Y.; Yao, G.M.; Luo, Z.W.; et al. Bioactive acylphloroglucinols with adamantyl skeleton from Hypericum sampsonii. Org. Lett. 2014, 16, 6322-6325. [CrossRef]

32. Reed, L.J.; Muench, H. A simple method of estimating fifty percent endpoints. Am. J. Hyg. 1938, 3, $493-497$. [CrossRef]

Sample Availability: Samples of compounds 1-10 are available from the authors. 